Keio J. Med. 31: 55-69, 1982

\title{
STUDIES ON HETEROGENEITY OF CULTURED CELL LINE (KU-2) DERIVED FROM HUMAN RENAL CELL CARCINOMA: MORPHOLOGY, KARYOTYPES AND GROWTH KINETICS BASED ON ANALYSIS OF 13 CLONES
}

\author{
KAZUHIKO NAGAKURA \\ Department of Urology, School of Medicine, Keio University, \\ Tokyo, Japan
}

(Received for publication August 10, 1982)

\begin{abstract}
The heterogeneity of cell line KU-2 derived from human renal cell carcinoma was studied utilizing single cell cloning method. Thirteen sublines named N-1-N-13 were yielded.

Observed morphologically as time lapsed, N-13 was different from other sublines in that it was a group of cells, spindle in shape maintained throughout, with a lower nuclear to cytoplasmic ratio and did not tend to pile up, with lower saturation density and long generation time.

Transmission electron microscopy showed different characteristics of each subline in the degree of development of cell surface microvilli and the amount of glycogen granules and lipid droplets in cytoplasm.

Karyotype analysis of the sublines showed 6 different modal chromosome numbers, but all of the sublines had common marker chromosomes, while clone N-5 had a proper giant metacentric marker chromosome.

Generation time determined by the fraction of labeled mitosis method ranged from $18.7 \mathrm{hr}(\mathrm{N}-10)$ to $25.6 \mathrm{hr}(\mathrm{N}-3)$, so did growth fraction from 0.83 to 1.00 .

Cloning of $\mathrm{KU}-2$ cell line revealed its heterogeneity detecting sublines with different biological properties. Subsequent separation of individual sublines with different cell kinetics from the heterogenous cell populations would provide clues to clarification of the role of cell kinetics in relation to other biological phenotypes of cancer cells.
\end{abstract}

\section{INTRODUCTION}

That neoplasms frequently develop as a clone from a single cell of origin is a concept gaining increased acceptance.,2 Many investigators have described 
tumor stemlines to explain neoplastic progression through sequential selection of mutant subpopulation derived from a common progenitor.,4 On the other hand, experimental results and clinical evidences suggest that cancers are composed of heterogenous cell populations, ${ }^{5-11}$ which have been produced by genetic lability on the original clones. ${ }^{*}$

Many cell lines derived from human cancers have been established, ${ }^{12,13}$ providing stable and reproducible research models. However, there are questions whether cells in culture are homogenous or heterogenous, and whether these have maintained their original functional properties, such as erythropoietine production in renal cell carcinoma, or not.

KU-2 cell line was derived from pulmonary metastasis of renal cell carcinoma in the patient with erythrocytosis. ${ }^{1+}$ Present study is undertaken to prove the heterogeneity of KU-2 cells by detection of difference in morphological features, growth kinetics and karyotypes of the sublines isolated by single cell cloning method.

\section{MATERIALS AND METHODS}

Cultured cell line $\mathrm{KU}-2$ derived from human hypernephroma and maintained in culture since 1976 was utilized as a parent cell line. KU-2 and its clone cell lines were maintained in monolayer in Eagle's minimum essential medium (Chiba Serum Institute, Chiba) supplemented with $10 \%$ fetal bovine serum (Flow Laboratories, Virginia) and $0.15 \mathrm{mg} / \mathrm{ml}$ carbenicillin in constant flow of $5 \% \mathrm{CO}_{2}-95 \%$ air with full humidity at $37^{\circ} \mathrm{C}$.

\section{1) Cloning of $\mathrm{KU}-2$}

$\mathrm{KU}-2$ cells in monolayer were harvested with tripsinization using a mixture of $0.25 \%$ trypsin (Chiba Serum Institute, Chiba) and $0.02 \%$ EDTA (Wako Junyaku, Osaka) in $1 / 15 \mathrm{M}$ phosphate buffer (PB). Single separated cells were suspended in fresh growth medium in concentration $10-20$ cells $/ \mathrm{ml}$ and $0.1 \mathrm{ml}$ of medium in cell suspention was inoculated in each well of Falcon microtestplate (Becton, Dickinson and Co., California). After inoculation, wells in plate accommodating single cell were marked and observed under phasecontrast microscopy everyday. Four days later $0.1 \mathrm{ml}$ fresh growth medium was added into the wells accomodating single cell and a half of the medium was changed with fresh medium every 4 days thereafter. When single separated cells grew and formed colonies, cells in each marked well were harvested with tripsinization and inoculated into one of 24 well multidish (Nune, Denmark) with $1 \mathrm{ml}$ fresh growth medium. After each well was filled with confluent cell sheet, cells were transferred to $25 \mathrm{~cm}^{2}$ plastic culture flask (Lux, Newburg, California) and these were named first passage of clone cell lines. 
For" study of saturation density, aliquots of $2 \times 10^{4}$ cells of each clone were seeded in 3 wells of the 24 well multidish containing $1 \mathrm{ml}$ growth medium in each. Growth medium was changed every 3 days and cells were counted everyday since 5 days after inoculation. The maximum number of cells in plateau phase of growth was employed as saturation density (cells per $\mathrm{cm}^{2}$ ). This experiment was repeated 3 times during 5 th to 7 th passage of clones.

\section{2) Morphological observation of clones}

Morphological observation on the 3rd passaged clone cells attached to culture flasks was carried out with a Nikon inverted microscope. For electron microscopy, cells of 13 clones were inoculated in Lab-Tek chamber (Miles Laboratories Inc., Illinois). Five days later the cell samples were rinsed with phosphate buffer (PB) and were fixed overnight in $2.5 \%$ glutaraldehyde. After the cells were rinsed again, those were postfixed in $1 \%$ osmium tetroxide for 2 hours, washed in $\mathrm{PB}$, dehydrated in graded ethanol and embedded in Epon 812. Thin sections of monolayer cells were doubly stained with uranyl acetate and lead citrate, and observed and photographed with Hitachi HS-9 electronmicroscope.

\section{3) Karyotype analysis of clones}

An aliquot of $5 \times 10^{4}$ cells of each clone was inoculated in Lab-Tek chamber with $1 \mathrm{ml}$ growth medium. Fourty eight hours later, cells were incubated with Corcemid $(0.2 \mu \mathrm{g} / \mathrm{ml}$, GIBCO, Grand Island. New York) for 4 hours and were treated with hypotonic solution $(0.075 \mathrm{~mol} / \mathrm{l}, \mathrm{KCL})$ for $20 \mathrm{~min}$ and with $3 \%$ Carnoy flxative in $0.075 \mathrm{~mol} / \mathrm{l} \mathrm{KCL}$ for $2 \mathrm{~min}$. Subsequently cells were fixed with pure Carnoy fixative for 5,5 and $30 \mathrm{~min}$, and dried with flame. For staining, conventional Giemsa method was used. Cells in metaphase were observed and photographed with Olympus Vanox light microscope under high magnification $\times 1000$.

\section{4) Growth kinetics of clones}

Cell kinetics of the 3rd passaged clones, N-1-13, was studied with fraction of labeled mitosis method (FLM method) of autoradiography using ${ }^{3} \mathrm{H}$-thymidine. Cells were harvested from culture flasks and suspended in fresh medium $2 \times 10^{4}$ cells $/ \mathrm{ml}$ in concentration. Five $\mathrm{ml}$ cell medium suspension were inoculated in ten petri dishes ( $5 \mathrm{~cm}$ in diameter, Becton, Dickinson and Co., California) in which two cover glass slips, $30 \times 12 \mathrm{~mm}$ in size, were already prepared. Seventy two hours later, growth medium in petri dishes was discarded and changed with fresh growth medium heated at $37^{\circ} \mathrm{C}$ containing $0.1 \mu \mathrm{Ci} / \mathrm{ml}{ }^{3} \mathrm{H}$-thymidine (specific activity $25 \mathrm{Ci} / \mathrm{mmol}$, R.C.C. Amersham, England). After 30 minutes labeling at $37^{\circ} \mathrm{C}$, incorporation of ${ }^{3} \mathrm{H}$-thymidine was stopped by changing the growth medium containing radioactive thymidine with fresh growth medium heated at $37^{\circ} \mathrm{C}$ con- 
taining $4 \times 10^{-5} \mathrm{mmol} / \mathrm{ml}$ cold-thymidine (GIBCO, New York) and cells were washed two times more and subsequently cultured with the same medium containing cold thymidine. Since labeling was finished, glass slips were taken out every 2 hours for 38 hours, washed twice with PB and fixed Carnoy flxative, a mixture of $25 \%$ acetic acid and $75 \%$ methanol, for $7 \mathrm{~min}$. Subsequently the cell samples were treated with $70 \%$ ethanol for 6 min and with cooled $0.2 \mathrm{~N}$ perchlolic acid for $20 \mathrm{~min}$, and dried in room temperature after those were washed twice in distilled water. The glass slips were dipped in the autoradiographic emulsion NR-M2 (Konishiroku Photo, Ind. Co., Tokyo) diluted with distilled water $(1: 1)$ and heated at $55^{\circ} \mathrm{C}$. After exposure in dark and dry box for 14 days, they were developed with Conidol-X (Konishiroku Photo, Ind. Co., Tokyo) and fixed with Fujifix (Fuji Photo Film Co. Ltd., Tokyo) for 5 minutes in each process. They were stained with $0.1 \%$ Kernecht-rot and were observed with a light microscope under magnification $\times 1000$. Labeled and non-labeled mitotic cells were counted and fraction of labeled mitoses in 100 mitotic cells was calculated in each sample. Cells with over 5 grains on their unclei were considered to be labeled cells. Then FLM curve drawn on a section paper and analysed by asymmetry method introduced by Takahashi and Mendelsohn. ${ }^{15}$

Growth fraction (GF), the fraction of proliferative cells relative to the whole population, was calculated with the equation, GF=labeling index/the fraction of $\mathrm{S}$ phase cells in relation to the growing cell population, which were obtained as byproducts of the FLM analysis.

\section{RESULTS}

\section{1) Cloning of $\mathrm{KU}-2$}

Thirteen clone cell lines were separated from KU-2 cells by single cell cloning method and named N-1 through N-13. Saturation density of the 13 clones is listed in Table 1. N-13 has cell density of $1.3 \times 10^{5}$ cells $/ \mathrm{cm}^{2}$, that is statistically smaller than those of other clones.

2) Morphological observation of clones

Phase contrast microscopy

Cells of other clones than N-13 living in culture flasks were polygonal shaped and had clear round nucleus with 2 to 4 nucleoli and various numbers of dense granules in cytoplasm. They tended to form round colonies on which cells in the middle area tended to pile up (Fig. $1 \mathrm{a}-\mathrm{d}$ ). Cells of clone $\mathrm{N}-13$ were distinguished from other clones under phase contrast microscopy. Most of $\mathrm{N}-13$ cells were spindle shaped with many dense granules, and did not make round colonies but more leaf-like at the edges. While cells of other clones than $\mathrm{N}-13$ continued to 
Table 1

Saturation density of $K U-2$ clones

\begin{tabular}{cc}
\hline Clones & Mean \pm S.D. $\left(\times 10^{5}\right.$ cells $\left./ \mathrm{cm}^{2}\right)$ \\
\hline $\mathrm{N}-1$ & $2.1 \pm 0.26$ \\
$\mathrm{~N}-2$ & $2.4 \pm 0.36$ \\
$\mathrm{~N}-3$ & $2.1 \pm 0.08$ \\
$\mathrm{~N}-4$ & $2.2 \pm 0.22$ \\
$\mathrm{~N}-5$ & $2.4 \pm 0.17$ \\
$\mathrm{~N}-6$ & $2.2 \pm 0.34$ \\
$\mathrm{~N}-7$ & $2.2 \pm 0.22$ \\
$\mathrm{~N}-8$ & $* \mathrm{~N} . \mathrm{D}$. \\
$\mathrm{N}-9$ & $2.2 \pm 0.29$ \\
$\mathrm{~N}-10$ & $2.3 \pm 0.13$ \\
$\mathrm{~N}-11$ & $2.2 \pm 0.29$ \\
$\mathrm{~N}-12$ & $2.1 \pm 0.22$ \\
$\mathrm{~N}-13$ & $1.3 \pm 0.33$
\end{tabular}

* N.D. $=$ not done

grow, piled up and freed from plastic surface after they were saturated in population, N-13 cells became to grow much slowly after they made confluent cell sheet and rarely piled up (Fig. 1 e,f). N-3 cells seemed to be intermediate type between $\mathrm{N}-13$ and other clones. They were similar to $\mathrm{N}-13$ cells for the following 3 to 4 days after passage, relatively large and spindle shaped, but sometimes were resembled with cells of other clones than N-13.

Transmission electronmicroscopy

Electronmicroscopically most cells of the sublines had nearly round nucleus and were attached with a few desmosomes each other, but no definite infolding was observed (Fig. 2). Microvilli on the cell surface were observed in all of the clones and mitotic cells were rarely observed.

On the other hand glycogen granules in cytoplasm were prominent in the sublines $\mathrm{N}-1,3,6,10$ and 12 , and lipid droplets were also prominent in $\mathrm{N}-1,8,9$ and $10 . \mathrm{N}-3,6$ and 13 had well developed microvilli resembling the brush border structure of renal proximal tubular cell (Fig. 3, 4, 5).

3) Karyotype analysis of clones

Of the 13 clones, 3 had individual modal numbers of chromosome of 62 in $\mathrm{N}-2,64$ in N-5 and 66 in N-9 and remaining 10 had the common modal numbers of 60 in N-11 and 12, of 63 in N-1, 3, 4, 6 and 13, and of 65 in N-7, 8 and 10 (Table 2).

Marker chromosomes were shared by all of the sublines, however N-5 had 


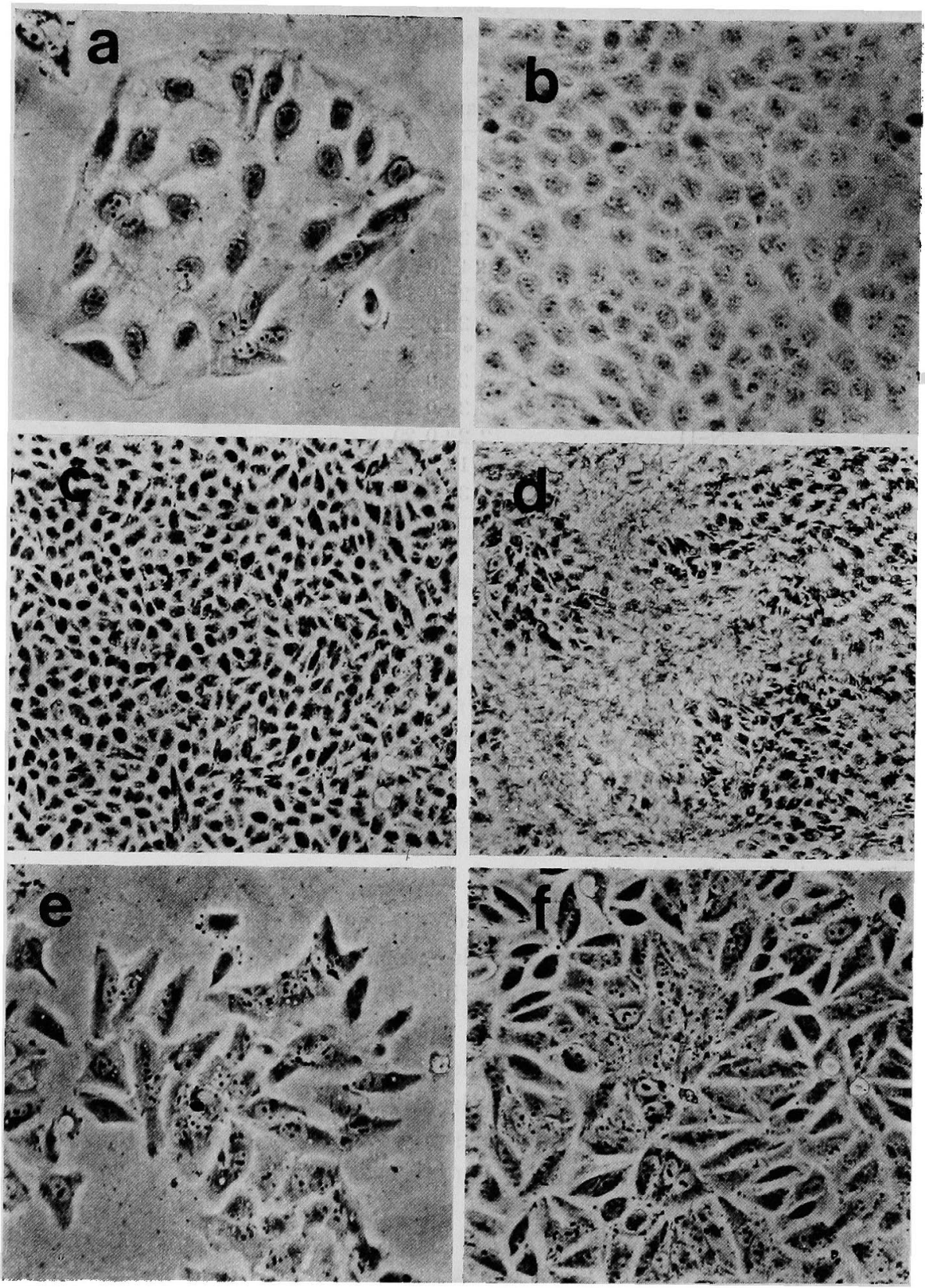

Fig. 1 Serial phase contrast microscopic view of $\mathrm{N}-5$ cells on day 2, 5, 7 and 9 (a, b, c, d) after passage, and of $\mathrm{N}-13$ cells on day 2 and 9 (e, f) after passage. Reduced from $\times 100$ 


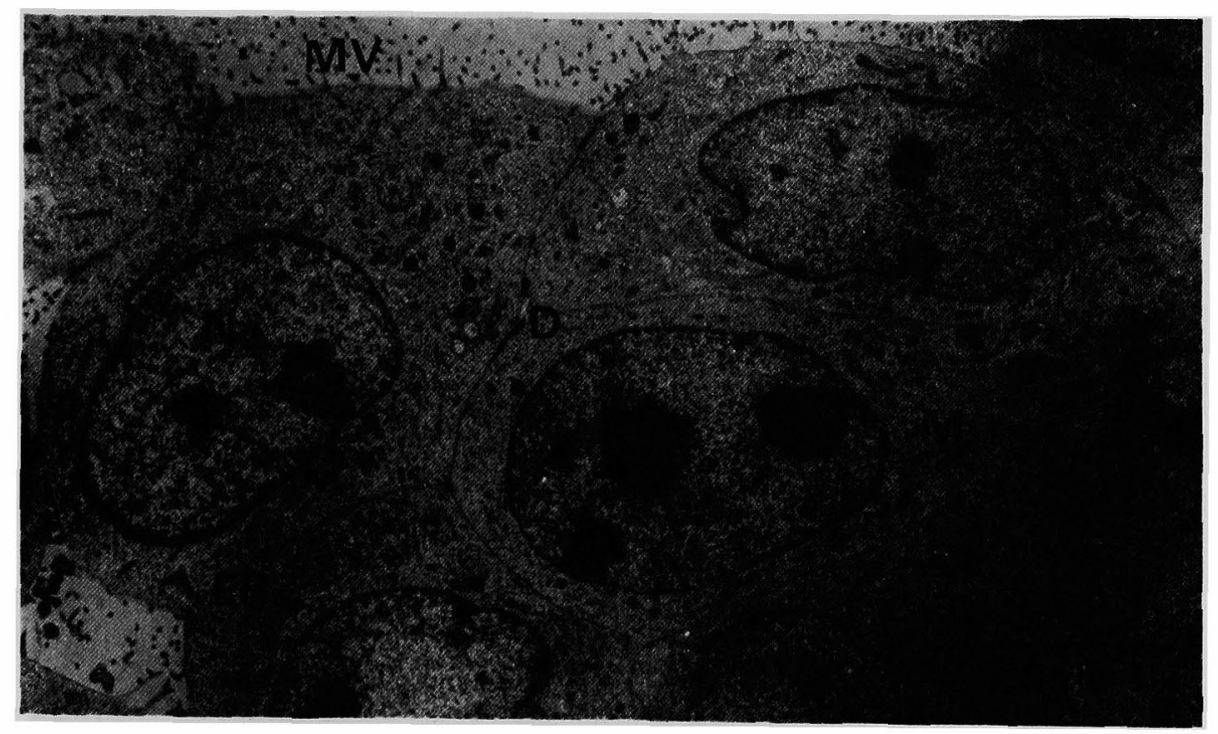

Fig. 2 Ultrastructure of $\mathrm{N}-2$ cells showing oval nuclei (N), moderately developed mitochondria (M) and endoplasmic reticulum (ER), microvilli (MV) projecting to growth medium and a few desmosomes (D). $\times 2000$
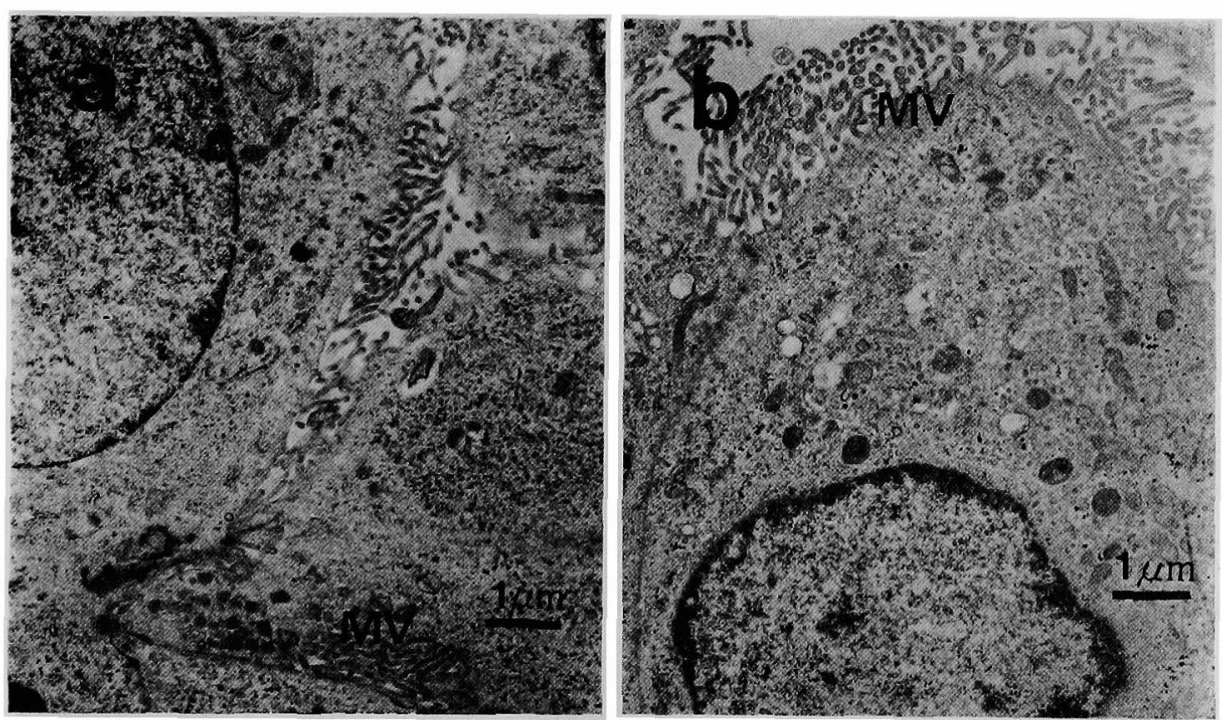

Fig. 3 Ultrastructure of $\mathrm{N}-3$ (a) and N-6 (b) cells showing well developed microvilli (MV). $\times 2000$ 


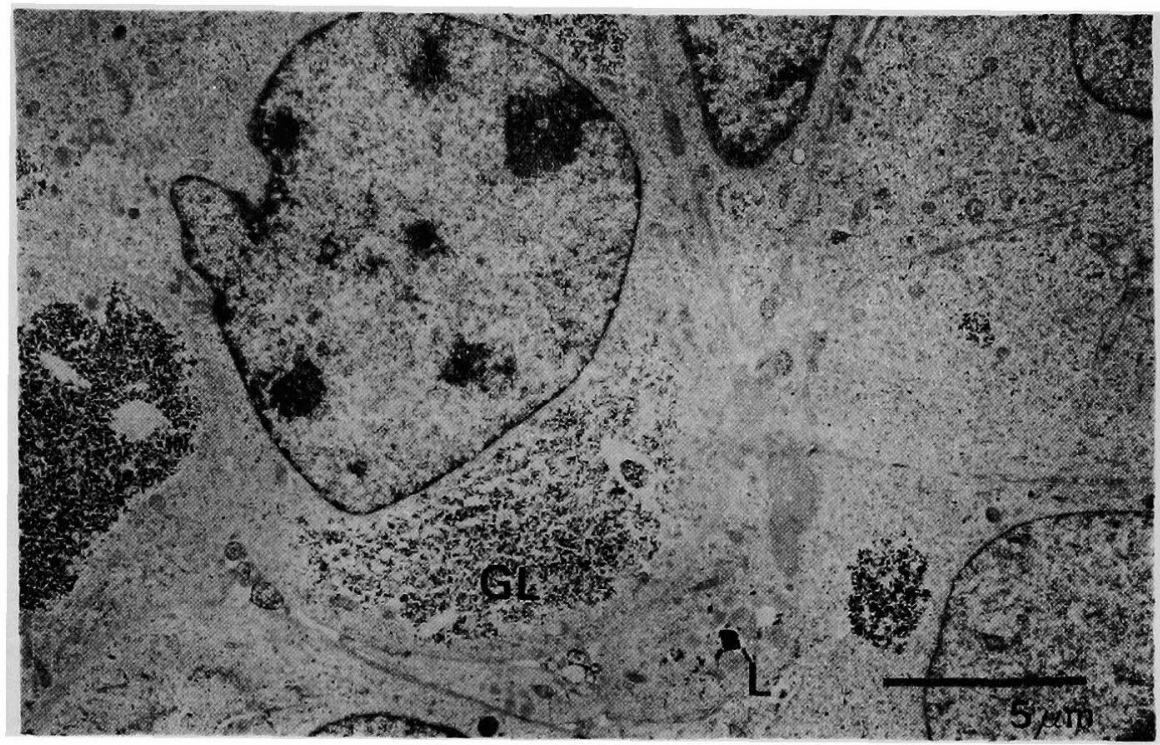

Fig. 4 Ultrastructure of N-10 cells showing abundant glycogen particles (GL) occupying one third of cytoplasm, a cluster of lipid droplets (L) and relatively small number of organelles. $\times 2000$

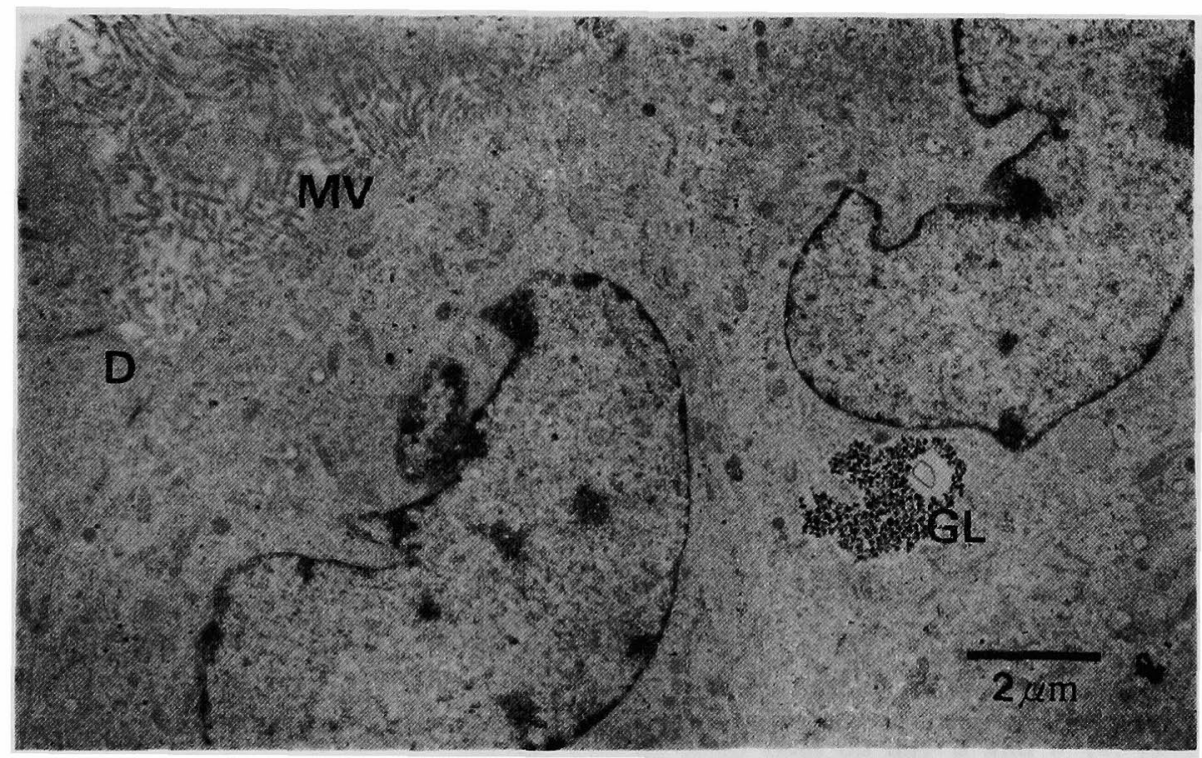

Fig. 5 Ultrastructure of $\mathrm{N}-13$ cells showing well developed microvilli, desmosomes and glycogen granules. $\times 2000$ 


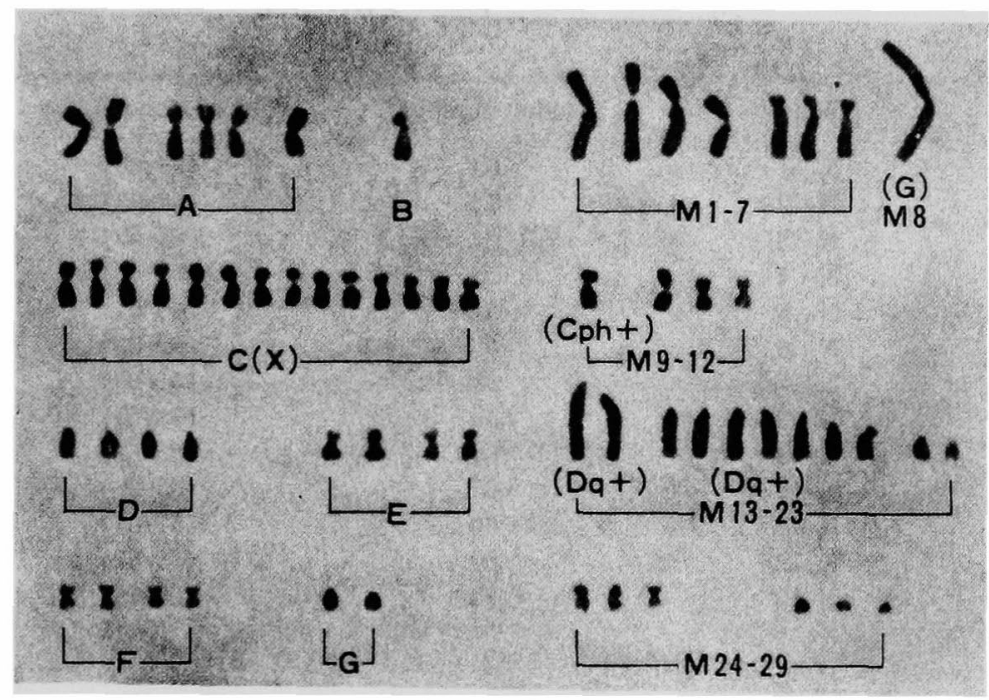

Fig. 6 Karyotype of Clones N-5 $($ mode $=64)$.

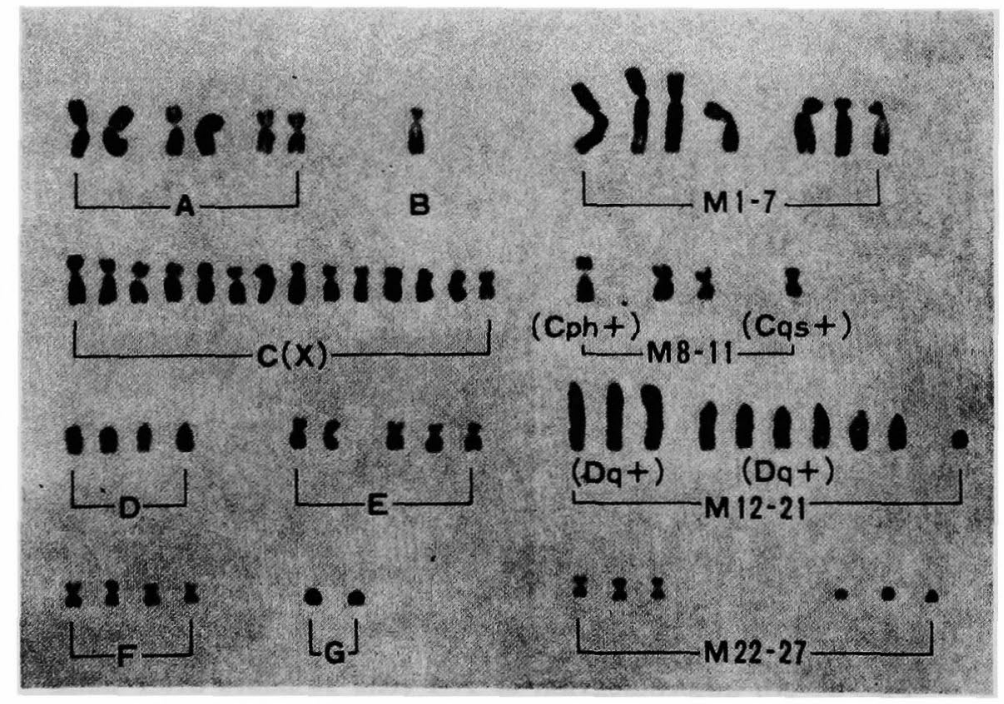

Fig. 7 Karyotype of Clone N-13 (mode $=63)$. 
Table 2

Chromosome numbers of $K U-2$ clones

\begin{tabular}{ccc}
\hline Clones & Modal number & (Range) \\
\hline $\mathrm{N}-1$ & 63 & $(59-63)$ \\
$\mathrm{N}-2$ & 62 & $(58-62)$ \\
$\mathrm{N}-3$ & 63 & $(62-65)$ \\
$\mathrm{N}-4$ & 63 & $(59-63)$ \\
$\mathrm{N}-5$ & 64 & $(60-64)$ \\
$\mathrm{N}-6$ & 63 & $(60-63)$ \\
$\mathrm{N}-7$ & 65 & $(61-66)$ \\
$\mathrm{N}-8$ & 65 & $(59-65)$ \\
$\mathrm{N}-9$ & 66 & $(63-67)$ \\
$\mathrm{N}-10$ & 65 & $(63-66)$ \\
$\mathrm{N}-11$ & 60 & $(57-64)$ \\
$\mathrm{N}-12$ & 60 & $(56-62)$ \\
$\mathrm{N}-13$ & 63 & $(59-63)$ \\
\hline
\end{tabular}

its own giant metacentric marker chromosome which had never been identified in other clones (Fig. 6, 7).

\section{4) Growth kinetics of clones}

FLM curve (Fig. 9) of the clones was obtained by counting fraction of labeled mitosis in autoradiograms (Fig. 8) and was analysed with the asymmetry method. Generation time (Tc) asym., corr of the 13 clones varied, ranging $18.7 \mathrm{hr}$

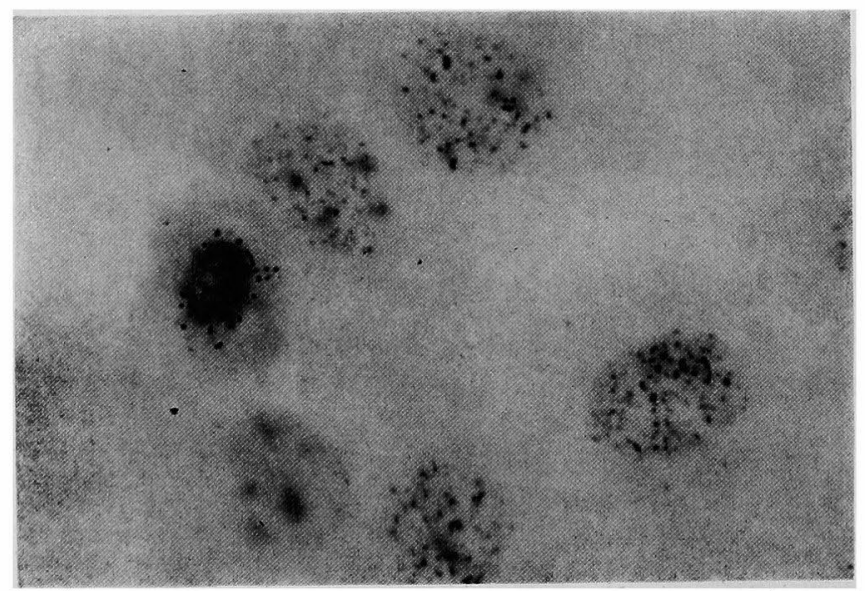

Fig. 8 An autoradiogram of N-1 cells 10 hours after pulse labeling with $0.1 \mu \mathrm{Ci} / \mathrm{ml}{ }^{3} \mathrm{H}$-thymidine. One labeled mitotic cell is observed. 


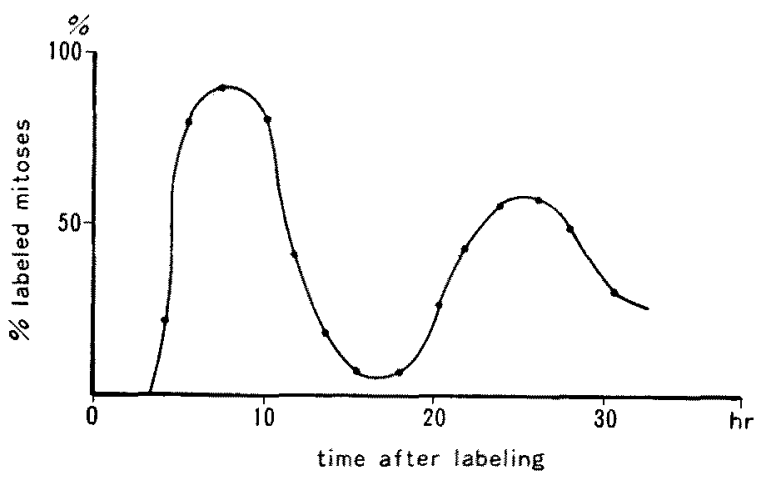

Fig. 9 F.L.M. Curve of $\mathrm{N}-1$.

of $\mathrm{N}-10$ to $25.6 \mathrm{hr}$ of $\mathrm{N}-3$. DNA synthesis phase (TS) area, corr. and post DNA

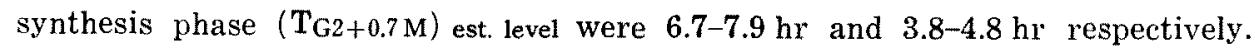

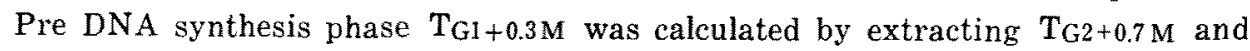
Ts from TC, and also varied, ranging from $7.7 \mathrm{hr}$ of $\mathrm{N}-1$ and 10 to $14.5 \mathrm{hr}$ of $\mathrm{N}-7$. Coefficient variation (CV) est. ranged from 33.6 to $46.8 \%$. Growth fraction was estimated over 0.8 in all clones, and 8 of the clones did not have quiescent cell compartment (Table 3 ).

Table 8

Cell cycle parameters of clone cell lines of $K U-2$

\begin{tabular}{|c|c|c|c|c|c|c|}
\hline Clones & $T \mathrm{G}_{1}+0.3 \mathrm{M}^{*}$ & $\begin{array}{c}\text { (Ts) } \\
\text { area, corr. }\end{array}$ & $\begin{array}{c}\left(\mathrm{TG}_{2}+0.7 \mathrm{M}\right) \\
\text { est. level }\end{array}$ & $\begin{array}{c}(\mathrm{TC}) \\
\text { asym. corr. }\end{array}$ & (CV) est. & $\begin{array}{l}\text { Growth } \\
\text { Fraction }\end{array}$ \\
\hline$N-1$ & $7.7 \mathrm{hr}$ & $7.0 \mathrm{hr}$ & $4.5 \mathrm{hr}$ & $19.2 \mathrm{hr}$ & $37.4 \%$ & 1.00 \\
\hline$N-2$ & 11.1 & 7.1 & 4.4 & 22.6 & 45.8 & 0.86 \\
\hline$N-3$ & 13.8 & 7.4 & 4.4 & 25.6 & 45.1 & 1.00 \\
\hline$N-4$ & 10.4 & 6.8 & 4.5 & 21.7 & 43.3 & 1.00 \\
\hline N- 5 & 11.1 & 6.5 & 4.2 & 21.8 & 42.8 & 0.96 \\
\hline$N-6$ & 8.6 & 7.9 & 4.1 & 20.6 & 33.6 & 0.83 \\
\hline$N-7$ & 14.8 & 6.2 & 4.2 & 25.2 & 34.3 & 1.00 \\
\hline$N-8$ & 10.4 & 7.2 & 3.8 & 21.4 & 37.8 & 0.98 \\
\hline$N-9$ & 10.0 & 7.4 & 4.4 & 21,8 & 42.8 & 1.00 \\
\hline $\mathrm{N}-10$ & 7.7 & 6.4 & 4.6 & 18.7 & 31.6 & 1.00 \\
\hline$N-11$ & 11.8 & 7.7 & 4.3 & 23.8 & 38.5 & 1.00 \\
\hline $\mathrm{N}-12$ & 11.5 & 7.3 & 4.3 & 23.1 & 41.0 & 1.00 \\
\hline $\mathrm{N}-13$ & 14.5 & 6.2 & 4.8 & 25.5 & 46.8 & 0.88 \\
\hline
\end{tabular}

* Values calculated by extracting $\mathrm{T}_{\mathrm{G} 2+7 \mathrm{M}}$ and $\mathrm{T}_{\mathrm{S}}$ from $\mathrm{T}_{\mathrm{C}}$. 


\section{DISCUSSION}

Homogeneity versus heterogeneity of an established human cancer cell line and mutageneity of monoclonal cells have been controversial. In the present study, scientific interest is directed to find whether sublines isolated from KU-2 by single cell cloning method have maintained the original functional properties such as erythropoietin production which had been shown by the original renal cell carcinoma heterotransplanted to nude mouse. ${ }^{16}$ As the first step of serial studies, the 13 sublines were analysis regarding morphological features, karyotype and growth kinetics.

Morphorogical observation of the 13 sublines under phase contrast microscopy showed differences in size, shape and nuclear to cytoplasmic ratio as well as in pattern of growth, such as saturation density. Brattain, i using human colonic carcinoma cell in culture, reported similar heterogeneity in morphorogical features and saturation density, and proved that the cells showing poor colony formation and low saturation density have poor tumorigenicity. Another reporti7 on cell differentiation in colonic carcinoma cells has also shown similar morphological features as shown by $\mathrm{N}-13$ cells, and lower tumorigenicity and cologeneity. Therefore the morphological features and growth behavior of N-13 cells may be characterized by low grade in malignancy and low grade aggressiveness in tumorigenicity or metastatic ability.

Electronmicroscopically renal cell carcinoma is characterized by large lipid droplets, abundunt glycogen particles, elongated and tortuous mitochondria, infolding of the plasma membrane and invagination of luminal surface as well as highly packed microvilli resembling the brush border structure of renal proximal tubular cells. ${ }^{18-20}$ In the preliminary studies of KU-2 cells by Katsuoka et al. ${ }^{14}$ revealed the characteristic ultrastructure resembling the brush border in the tumor reproduced in a nude mouse by inoculation of KU-2 cells. This morphological characteristic feature was found to be maintained by the sublines of $\mathrm{KU}-2$ such as $\mathrm{N}-3,6$ and 13 , even after long term culture process.

In general, distinct difference of chromosome exists between cancer and normal cells for determination of their phenotypes." Also the transition of chromosome number from diploid to tetraploid, triploid and aneuploid is accompanied by the progression in malignancy and dedifferentiation. ${ }^{21.22}$ In the present study, modal chromosome numbers of the sublines of KU-2 are aneuploid, ranging from 60 to 66 , having been decreased from 72 when KU-2 was established in 1976. ${ }^{16}$ The results indicate that $\mathrm{KU}-2$ cells are not homogenous but composed of heterogenous cell population in karyotype. Also these 13 sublines have arisen from a single stemcell because of the presence of common marker chromosomes.

There are many reports ${ }^{23-26}$ dealing with cell kinetics of cultured cell lines, 
in which generation time in general is shown to range from 15 to $30 \mathrm{hr}$ with $\mathrm{T}_{\mathrm{S}}$ ranging from 5 to $10 \mathrm{hr}$ and $\mathrm{T}_{\mathrm{G} 2}$ from 3 to $5 \mathrm{hr}$. Although generation time also varies depending upon method utilized, ${ }^{25}$ the difference in $T_{G 1}$ is mainly responsible for the difference in generation time. Generation time of the sublines of KU-2 in the present study showed a variety of time ranging from $18.7 \mathrm{hr}$ of $\mathrm{N}-10$ to $25.6 \mathrm{hr}$ of $\mathrm{N}-3$. However, $\mathrm{T}_{\mathrm{G} 2}+0.7 \mathrm{M}$ and $\mathrm{T}_{\mathrm{S}}$ were $3.8-4.8 \mathrm{hr}$ and $6.2-7.9$ hr respectively with $\mathrm{T}_{\mathrm{G} 2}$ and $\mathrm{Ts}$ of all 13 sublines falling into a very narrow range, thus generation time largely depended upon $\mathrm{T}_{\mathrm{Gl}}$, corresponding to the results of previous reports on cell kinetics. ${ }^{23,25,26}$ However, biological implication of cell kinetics in culture is not easy to interpret because of presence of environmental difference between in vivo and in vitro setup.

It is known by in vivo experiment that generation time of cancer cells is longer than that of cells from which the cancer is arisen, ${ }^{25-27}$ however further malignant degeneration and dedifferentiation are, in the majority of cases, accompanied by increased growth rate of the tumor. ${ }^{28,29}$

Relation between cell cycle in vitro and tumorigenicity and metastasizing ability in vivo has also studied by many investigators. Danielson ${ }^{6}$ isolated 2 sublines from a murine mammary tumor, and showed that one of 2 sublines capable of growing in semisolid medium had short doubling time as well as high colonial efficiency and tumorigenicity. Dexter 17 demonstrated decreased growth rate as well as loss of tumorigenicity and appearance of cellular differentiation in colonic carcinoma cell line by treatment with a maturation inducing agent. In addition there was a unique study on cell cycle dependency of metastatic ability in a mouse fibrosarcoma cell line, ${ }^{30}$ demonstrating the highest lung colony forming efficiency of cells in DNA synthesis phase and the lowest of cells in G1 phase. Even though it is difficult to determine whether cell cycle dependency is caused by different intrinsic properties of cells in different cell cycle phases or by mere ability of cell proliferation, it is considered that the rapid growth plays a major role for high tumorigenicity and other aggressive properties of neoplasms both in in vivo and in vitro setup. Therefore, the sublines, N-1 and 10 both characterized by rapid generation time and high growth fraction, can be considered more malignant than other sublines.

Studies on cell kinetics of tumor has greatly contributed to establish principal concept regarding efficacy of various therapeutic modalities, ${ }^{31}$ as witnessed by progress in treatment of leukemia. ${ }^{32}$ The relation between cell kinetics and anticancer treatment with drugs can be briefly stated that the efficacy of the majority of anticancer drugs is, from the theoretical point of view, directly proportional to rapidity of generation time, high growth fraction and high labeling index. Therefore, chemosensitivity of cancer cell must be assessed in the light of cell kinetics, if one is to achieve better therapeutic effect, and elucidation of the 
difference among closely related but functionally distinct sublines might help for better understanding of the strategy against neoplasms.

Current investigation has disclosed differences in cell kinetics among 13 sublines (N-1-N-13) separated from KU-2 by single cell cloning method. The demonstrated differences can, together with the results of karyotype and morphological observation, afford proof of heterogeneity of KU-2. Of the 13 clones, N-13 had low growth rate, low saturation density and morphological findings characterized by well differentiated pattern, representing low grade in malignancy. However, in other clones, no clear correlation was noted between cell kinetics and morphological features. The difference in karyotype of the 13 clones also did not reflect the difference in other properties.

\section{ACKNOWLEDGEMENT}

The author is deeply indepted to Prof. Hiroshi Tazaki for his advise and encouragement throughout this study and also appreciate Mr. Yoshihiro Kinoshita, Miss Yuko Uchida and the colleagues of department of Urology for helpful suggestions and assistances. This work was supported in part by a Grant-in-Aid for Cancer Research (53-19 and 55-22) from the Ministry of Health and Welfare and by a Grant-in-Aid for Scientific Research from the Ministry of Education, Science and Culture.

(A part of this study was presented at 76th Annual Meeting of American Urological Association in May, 1981, Boston, U.S.A.).

\section{REFERENCES}

1. Sandberg, A. A. and Hossefeld, D. K.: Chromosomal abnormalities in human neoplasia. Ann. Rev. Med. 21: 379-408, 1970

2. Sandberg, A. A.: Chromosomes and cancer. In: The chromosomes in human cancer and leukemia. Elsevier, New York, 1980, 426-457

3. Fialkow, P. J.: Clonal origin and stem cell evolution of human tumors. In: Genetics of human cancer, Raven Press, New York, 1977, 439-453

4. Nowell, P. C.: The clonal evolution of tumor cell populations. Science 194:23-28, 1976

5. Danielson, K. G., Anderson, L.W. and Hosick, H. L.: Selection and characterization in culture of mammary tumor cells with distinctive growth properties in vivo. Cancer Res. 40: 1812-1817, 1980

6. Dexter, D. L., Kowalski, H. M., Blazar, B. A. et al.: Heterogeneity of tumor cells from a single mouse mammary tumor. Cancer Res. 38: 3174-3181, 1978

7. Brattain, M. G., Fine, W. D., Khaled, F. M. et al.: Heterogeneity of malignant cells from a human colonic carcinoma. Cancer Res. 41: 1751-1756, 1981

8. Shapiro, J. R., Yung, W. A. and Shapiro, W. R.: Isolation, karyotype, and clonal growth of heterogeneous subpopulations of human malignant gliomas. Cancer Res. 41: 2349-2359, 1981

9. Raz, A., MacLellan, W.L., Hart, I. R. et al.: Cell surface properties of B16 melanoma variants with differing metastatic potential. Cancer Res. 40: 1645-1651, 1980.

10. Barranco, S.C., Haenelt, B. R. and Gee, E. L.: Differential sensitivilities of five rat hepatoma cell lines to anticancer drugs. Cancer Res. 38: 656-660, 1978 
11. Byers, V.S. and Johnston, J. O.: Antigenic differences among osteogenic sarcoma tumor cells taken from different location in human tumors. Cancer Res. 37 : 3173-3183, 1977

12. Williams, R. D.: Human urologic cancer cell lines. Invest. Urol. 17: 359-363, 1980

13. Tazaki, H.: Fundamentals and clinical application of cell culture in urology. Jap. J. Urol. 71: 1132-1146, 1980 (in Japanese)

14. Katsuoka, Y., Baba, S. Sata, M. et al.: Transplantation of human renal cell carcinoma to the nude mice: As an intermediate of in vivo and in vitro. J. Urol. 115: $373-376,1976$

15. Mendelsohn, M. L. and Takahashi, M.: A critical evaluation of the fraction of labeled mitoses method as applied to the analysis of tumor and other cell cycles. In: The Cell Cycle and Cancer, Marcel Dekker Inc., New York, 1971, 58-95.

16. Katsuoka, Y.: Functional and morphological observation of human renal cell carcinoma utilizing nude mouse and cell culture system. Jap. J. Urol. 69: 285-303, 1978 (in Japanese)

17. Dexter, D. L., Barbasa, J. A. and Calabresi, P.: N,N-Dimethylformamide-induced alteration of cell culture characteristics and loss of tumorigenicity in cultured human colon carcinoma cells. Cancer Res. 39: 1020-1025, 1979

18. Yokoyama, M.: Ultracytochemical and morphological studies of human renal cell carcinoma. J. Urol. 108: 62-69, 1972.

19. Sun, C. N., Bissada, N. K. and White, H. J.: Spectrum of ultrastructural patterns of renal cell adenocarcinoma. Urol. 2: 195-200, 1977.

20. Bannayan, G. A. and Lamm, D. L.: Renal cell tumors. Pathol. Ann. 15: 271-308, 1980

21. Sandberg, A. A.: Chromosome markers and progression in bladder cancer. Cancer Res. 37: 2950-2956, 1977

22. Javadpour, N., Roy, J. B., Bottomley, R. et al.: Combined cell surface antigens and chromosomal studies in bladder cancer. Urology 19: 29-32, 1982

23. Kato, T.: Cell kinetics of the bladder carcinoma. 1. Cell cycle analysis of the cultured human bladder carcinoma cells. Jap. J. Urol. 67: 491-496, 1976 (in Japanese)

24. Deffendi, V. and Manson, L. A.: Analysis of the life-cycle in mammalian cells. Nature 198: 359-361, 1963

25. Fujita, T.: Analysis of cell proliferation. In: New Cytology. edited by Senoo, S. Asakura Shoten, Tokyo, 1965, 605-637 (in Japanese)

26. Cleaver, J. E.: Interphase replication of DNA and the cell cycle. In: Thymidine metabolism and cell kinetics. North Holland Pub. Co., Amsterdam, 1967, 104-136.

27. Buehring, G. C. and Williams, R. R.: Growth rates of normal and abnormal human mammary epithelia in cell culture. Cancer Res. 36: 3742-3747, 1976

28. Gray, J. M. and Pierce, G. B.: Relationship between growth rate and differentiation of melanoma in vivo. J. Natl. Cancer Inst. 32: 1201-1210, 1964.

29. Fulker, M. J., Cooper, E. H. and Tanaka, T.: Proliferation and ultrastructure of papillary transitional cell carcinoma of the human bladder. Cancer 27: 71-82, 1971

30. Suzuki, N., Frapart, M., Grdina, D. J. et al.: Cell cycle dependency of metastatic lung colony formation. Cancer Res. 37: 3690-3693, 1977

31. Schabel, F.M. Jr.: The use of tumor growth kinetics in planning "Curative" chemotherapy of advanced solid tumors. Cancer Res. 29: 2384-2389, 1969.

32. Lampkin, B. C., Nagao, T. and Mauer, A. M.: Synchronization and recruitment in acute leukemia. J. Clin. Invest. 50: 2204-2214, 1971 